University of Nebraska - Lincoln

DigitalCommons@University of Nebraska - Lincoln

1986

INFLUENCE OF LIGNIN ON DIGESTIBILITY OF FORAGE CELL WALL MATERIAL

H. G. Jung

USDA-ARS

Kenneth P. Vogel

University of Nebraska-Lincoln, kvogel1@unl.edu

Follow this and additional works at: https://digitalcommons.unl.edu/usdaarsfacpub

Jung, H. G. and Vogel, Kenneth P., "INFLUENCE OF LIGNIN ON DIGESTIBILITY OF FORAGE CELL WALL MATERIAL" (1986). Publications from USDA-ARS / UNL Faculty. 1889.

https://digitalcommons.unl.edu/usdaarsfacpub/1889

This Article is brought to you for free and open access by the U.S. Department of Agriculture: Agricultural Research Service, Lincoln, Nebraska at DigitalCommons@University of Nebraska - Lincoln. It has been accepted for inclusion in Publications from USDA-ARS / UNL Faculty by an authorized administrator of DigitalCommons@University of Nebraska - Lincoln. 


\title{
INFLUENCE OF LIGNIN ON DIGESTIBILITY OF FORAGE CELL WALL MATERIAL
}

\author{
H. G. Jung ${ }^{1}$ and K. P. Vogel ${ }^{2}$ \\ U.S. Department of Agriculture, Clay Center, NE 68933 \\ and \\ Lincoln, NE 68583
}

\begin{abstract}
One-hundred-ninety-four grass samples, representing eight species, were used to determine the relationships of in vitro forage dry matter, cell wall, hemicellulose and cellulose digestibilities with lignin concentration. Linear regressions indicated that dry matter digestion was inhibited to a lesser degree $(P<.05)$ by lignin concentration than was cell wall digestion. Results for linear regressions of hemicellulose and cellulose digestibilities as functions of lignin concentration showed a greater $(\mathrm{P}<.05)$ effect of lignin on cellulose digestion. Smooth bromegrass and switchgrass were collected at both Clay Center and Mead, NE; for all digestibility measures, the Clay Center samples gave stronger $(\mathbf{P}<.05)$ negative correlations with lignin. A comparison of linear and curvilinear models indicated that, for all digestion measurements, the curvilinear model was a better $(P<.05)$ description of relationships with lignin concentration. For all digestibility measures, lignin's inhibiting effect declined at higher lignin concentrations. The curvilinear models did not show significant differences among the digestibility measures for effect of lignin. The demonstration that the forage digestibility response to lignin's inhibitory effect is curvilinear in nature suggests that the mechanism of lignin's inhibition is complex.
\end{abstract}

(Key Words: Lignin, Forage, Digestibility, Cell Walls, Hemicellulose, Cellulose.)

\section{Introduction}

The negative relationship between forage digestibility and lignin concentration has been observed for over $50 \mathrm{yr}$ (Woodman and Stewart, 1932). Studies have demonstrated strong negative correlations of dry matter and fiber digestion with forage lignin concentration (Mowat et al., 1969; Allinson and Osbourn, 1970; Minson, 1971). Chemical analysis of forage cell walls indicates that lignin is covalently bound to the hemicellulose fraction of the cell wall, but no evidence for similar linkages between cellulose and lignin fractions has been demonstrated (Bacon, 1979; Morrison, 1979). These analytical results suggest that because of the direct association between hemicellulose and lignin, inhibition of hemicellulose digestion due to increasing lignin concentration would be greater than inhibition of cellu-

${ }^{1}$ USDA, ARS, Roman L. Hruska U.S. Meat Anim. Res. Center.

${ }^{2}$ USDA, ARS, Univ. of Nebraska.

Received September 13, 1985.

Accepted December 18, 1985. lose digestion by lignin. Experiments with chemically delignified forages generally indicate that removal of lignin improves hemicellulose digestibility to a greater degree than of cellulose (Ford, 1978; Morrison, 1983). However, Bunting et al. (1984) have reported that cellulose digestibility is increased more than hemicellulose with delignification by ozone treamtent.

This study tested the previously stated hypothesis regarding lignin's inhibition of hemicellulose and cellulose digestibilities using nonmodified forages. A further hypothesis was tested: cell wall degradation is more influenced by lignin than is total dry matter digestion. Physiological maturity of forages was used to vary degree of lignification and digestibility was determined in an in vitro system.

\section{Materials and Methods}

Grass samples (194 total), representing eight species, were collected from two sites in Nebraska during the summer of 1983. The grasses were sampled at various stages of maturity, which are described in table 1 . At Clay Center, orchardgrass (Dactylis glomerata), smooth bromegrass (Bromus inermis) and 
TABLE 1. GROWTH STAGES OF GRASS SAMPLES

\begin{tabular}{|c|c|c|}
\hline $\begin{array}{l}\text { Collection } \\
\text { site }\end{array}$ & Forage species & Growth stages \\
\hline Clay Center & Orchardgrass & $\begin{array}{l}\text { Five samples from vegetative through heading } \\
\text { during primary growth, three samples from } \\
\text { vegetative through heading during regrowth. }\end{array}$ \\
\hline Clay Center & Smooth bromegrass & $\begin{array}{l}\text { Eight samples from vegetative through mature } \\
\text { seed stages. }\end{array}$ \\
\hline Clay Center & Switchgrass & $\begin{array}{l}\text { Nine samples from vegetative through mature } \\
\text { seed stages. }\end{array}$ \\
\hline Mead & Smooth bromegrass & Vegetative and heading stage samples. \\
\hline Mead & $\begin{array}{l}\text { Switchgrass, indiangrass, big bluestem, } \\
\text { Caucasian bluestem, sand bluestem, } \\
\text { and a big } \times \text { sand bluestem hybrid }\end{array}$ & Vegetative, boot and heading stage samples. \\
\hline
\end{tabular}

switchgrass (Panicum virgatum) were collected. As part of grass variety trials at Mead, Nebraska the following samples were collected: smooth bromegrass (six varieties), switchgrass and indiangrass (Sorghastrum nutans; five varieties of each species), big bluestem (Andropogon gerardi; two varieties), Caucasian bluestem (Bothriochloa caucasius), sand bluestem (Andropogon hallii and a big $x$ sand bluestem hybrid (one variety of each species). Each of the grass species and varieties from Mead was collected from three replicate plots. All samples were cut by hand at 2 to $4 \mathrm{~cm}$ above the soil. Clipped samples were placed on dry ice for transport to the laboratory. The entire grass plant was then frozen, lyophilized and ground to pass a 1 -mm screen.

Digestibility of these grass samples was estimated by 48 -h in vitro fermentations. For estimates of in vitro dry matter disappearance (IVDMD), 500-mg samples were placed in 50-ml plastic culture tubes with screw caps. Each tube was inoculated with $30 \mathrm{ml}$ of a ruminal fluid:McDougall's buffer $(1: 4)$ solution (McDougall, 1948). Ruminal fluid was collected from a ruminal-fistulated steer after an overnight fast $(16 \mathrm{~h})$ and filtered through eight layers of cheesecloth. The steer was maintained on an alfalfa:mixed grass hay diet. Samples were incubated for $48 \mathrm{~h}$ at $39 \mathrm{C}$ with occasional shaking. At the end of $48 \mathrm{~h}, .5 \mathrm{ml}$ of amyl alcohol, $1 \mathrm{ml}$ of $6 \mathrm{~N} \mathrm{HCl}$ and $5 \mathrm{ml}$ of pepsin: $\mathrm{H}_{2} \mathrm{O}$ solution (approximately 72,000 units) were added to each tube. The samples were incubated for an additional $48 \mathrm{~h}$ for protein hydrolysis at $39 \mathrm{C}$. At the end of digestion, samples were filtered through medium-porosity Gooch crucibles. Replicate samples for estimates of fiber component digestion were run concurrently using the same procedure, but the digestion was halted after the fermentation stage. These samples were centrifuged at 3,000 $\times \mathrm{g}$ for $30 \mathrm{~min}$, and the supernatant discarded. For each of the two digestion estimates, each grass sample was fermented in duplicate on two separate occasions.

The grass samples and their fermentation residues were analyzed for dry matter by drying overnight at $100 \mathrm{C}$. Crude protein was estimated as Kjeldahl $\mathrm{N} \times 6.25$ (AOAC, 1975). Fiber composition was determined by the detergent system, using the sequential analysis scheme to minimize interfering substances (Van Soest and Robertson, 1980). Seventy-two percent sulfuric acid was used to solubilize cellulose and isolate crude lignin plus ash. Total cell wall was defined as the neutral detergent fiber value. Hemicellulose, cellulose and lignin were calculated by difference (hemicellulose = neutral detergent fiber minus acid detergent fiber, cellulose $=$ acid detergent fiber minus acid detergent lignin, lignin $=$ acid detergent lignin minus ash). Lignin concentrations are overestimated by this procedure because of cutin contamination of the acid detergent lignin preparation, but grasses are generally low in cutin content.

The smooth bromegrass samples collected at Mead were part of a selection experiment that included six varieties of smooth bromegrass planted in a nursery in a randomized completeblock design with six replicate plots. The other 
samples from Mead were collected from a larger experiment that included 20 switchgrass, 14 big and sand bluestems, 9 indiangrasses and 3 old world bluestems planted in a nursery in a randomized complete-block with six replicates. The samples from Mead were analyzed as a randomized complete-block for forage species and variety differences. The Clay Center samples were unreplicated and only used in regression analysis. The data were analyzed for significant linear and non-linear regressions for the entire data set and individual species by least-squares techniques to determine the validity of the hypotheses proposed. The SAS computational package was used for all analyses (SAS, 1982).

\section{Results and Discussion}

The grass species in this study can be divided in to two groups based upon their photosynthetic pathways. Those species which possess the reductive pentose pathway are referred to as $\mathrm{C}_{3}$ species (Waller and Lewis, 1979). Grasses possessing the 4-carbon pathway (dicarboxylic acid) are $\mathrm{C}_{4}$ species. The grass samples collected for this study ranged widely in both composition and apparent digestibility (table 2). Data for composition of hemicellulose, cellulose and lignin of the forages are presented on a percentage of plant cell wall basis because this presentation shows more clearly the changes in cell wall composition with advancing physiological maturity. No significant effects on composition or digestibility were found for grass varieties within species for the Mead samples; therefore, no further discussion of varieties will be included.

Trends in composition and digestibility of the grass species were as expected; increasing cell wall concentration and decreasing digestibility with maturation (table 2). As the total cell wall concentration of the grasses increased, the lignin concentration of the cell wall increased exponentially (figure 1). Orchardgrass, however, showed a decrease in lignin concentration of the cell wall as the plant matured (table 2). Figures 2 and 3 illustrate the relationships that exist among the fiber components. The hemicellulose component of the cell wall declined in a linear fashion as the cellulose component increased (figure 2). Although not evident in the preceding relationship, the hemicellulose component of the cell wall appears to reach a minimum of approximately $40 \%$ of the cell wall when viewed as a curvilinear decline against cell wall lignin concentration (figure 3 ). Cellulose concentration in grass cell walls did not show a relationship $(\mathrm{P}>.05)$ with lignin concentration of the cell wall.

The aforementioned trends were true for both the entire data set and for most individual grass species. The reasons for these changes are twofold. First, the percentage of the plant dry matter represented by stem material increases during maturation, and secondly stems contain more cell wall and lignin than do leaves (Griffin and Jung, 1983; Wilman and Altimimi, 1984). Both leaves and stems show increases in lignified sclerenchyma cells during maturation (Wilkins, 1972). The various cell types found in forages have been shown to differ in their digestibility and generally the least digestible forms contain the highest concentrations of lignin (Akin and Burdick, 1975; Akin et al., 1983).

Although only two species of $\mathrm{C}_{3}$ grasses were sampled, differences between $C_{3}$ and $C_{4}$ grasses for composition and digestibility were seen in the data (table 2 ). The $\mathrm{C}_{4}$ species had higher concentrations of cell wall material that appeared to be less digestible at all stages of maturity. Differences in hemicellulose and cellulose concentration in the cell walls did not differ substantially between the grasses, but again the $\mathrm{C}_{4}$ species tended to exhibit lower digestibilities. Lignin concentration in the cell wall material of $\mathrm{C}_{4}$ grasses was slightly greater than that of $\mathrm{C}_{3}$ species and also apparent digestibility of the lignin was less. Ford et al. (1979) have reported similar results and these agree with differences known to exist in cell types of $\mathrm{C}_{3}$ and $\mathrm{C}_{4}$ tissues (Akin and Burdick, 1975; Akin et al., 1983).

The linear relationships between digestibility of forage components and lignin concentration (on a dry matter basis) are given in table 3 . All regression coefficients for the digestibility measurements were significant, except for orchardgrass and the big $x$ sand bluestem hybrid. In the case of the orchardgrass, this may have been due to the unusual trend toward decreasing lignin concentration in the cell wall as the grass matured. The explanation for the exceptionally large standard errors seen for the hybrid's regression coefficients is unknown. It was expected that the regression of fiber digestibilities on lignin as a percentage of the cell wall would give a better fit to the model because lignin is a component of the cell wall; instead, it was found that lignin as a percentage of the dry 
JUNG AND VOGEL

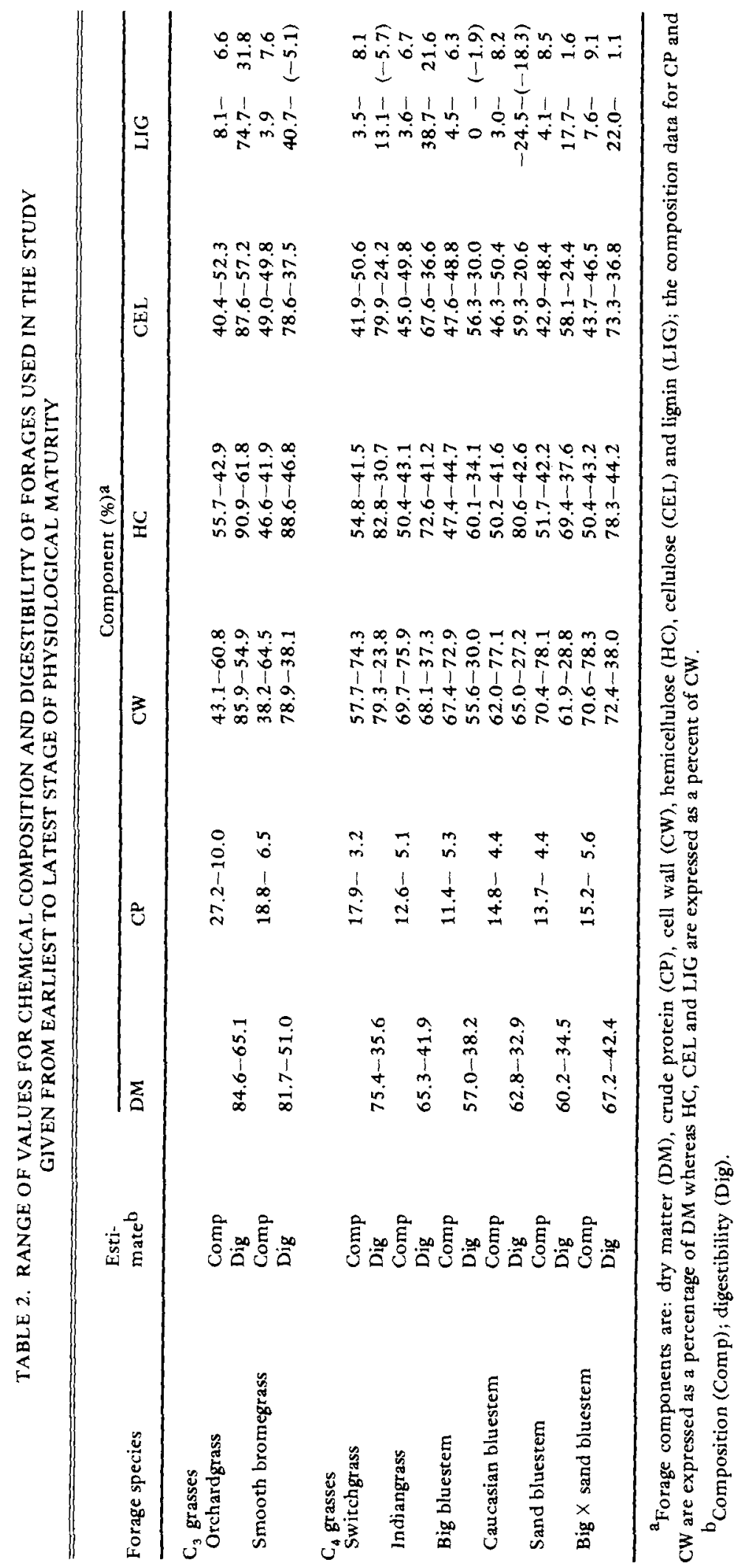


matter gave equal or better fit to the model for both the entire data set and most individual species. A similar phenomena was observed by Mowat et al. (1969). This may simply relate to the greater precision of dry matter determination relative to fiber measurements, rather than a biologically important difference.

A test of the second hypothesis, that dry matter digestion is less affected by lignin content than is cell wall digestion, revealed that this difference was significant for the smooth bromegrass and switchgrass samples, and for the entire data set. For all species except orchardgrass, the numerical values for dry matter and cell wall digestibility regression coefficients trended in the direction of a greater inhibition of cell wall digestion by lignin (table 3 ). The first hypothesis, that lignin inhibits hemicellulose digestion to a greater degree than cellulose digestion, was found to be false (table 3 ). In fact, the opposite relationship was found to be true $(\mathrm{P}<.05)$ for switchgrass and the overall data set. Most of the other grasses also showed trends in this direction. This is in direct conflict with Morrison's (1983) observation that removal of lignin from wheat and barley straws

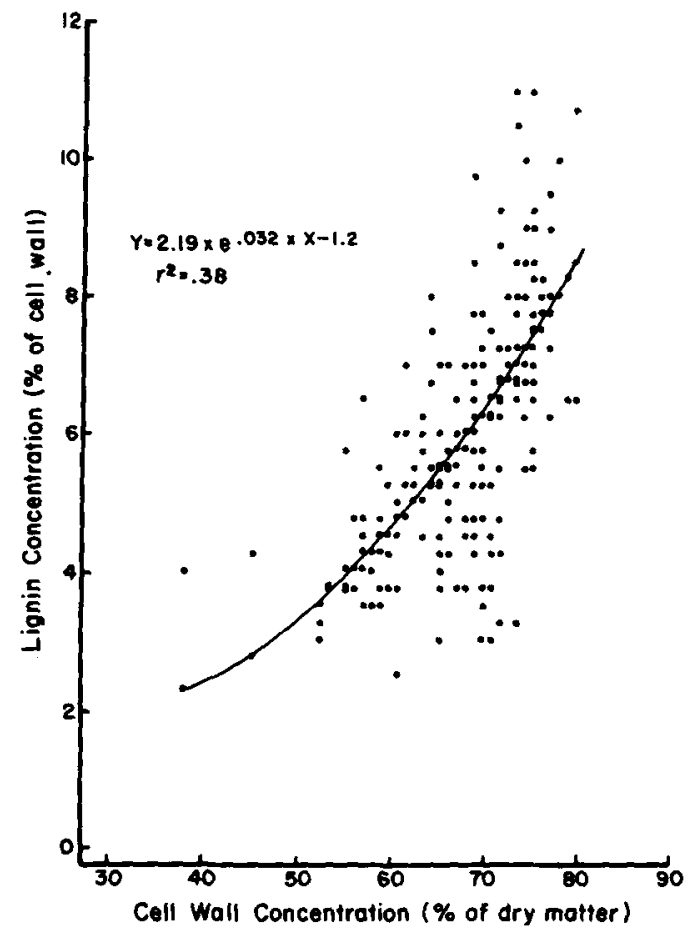

Figure 1. Relationship of grass lignin concentration with cell wall concentration.

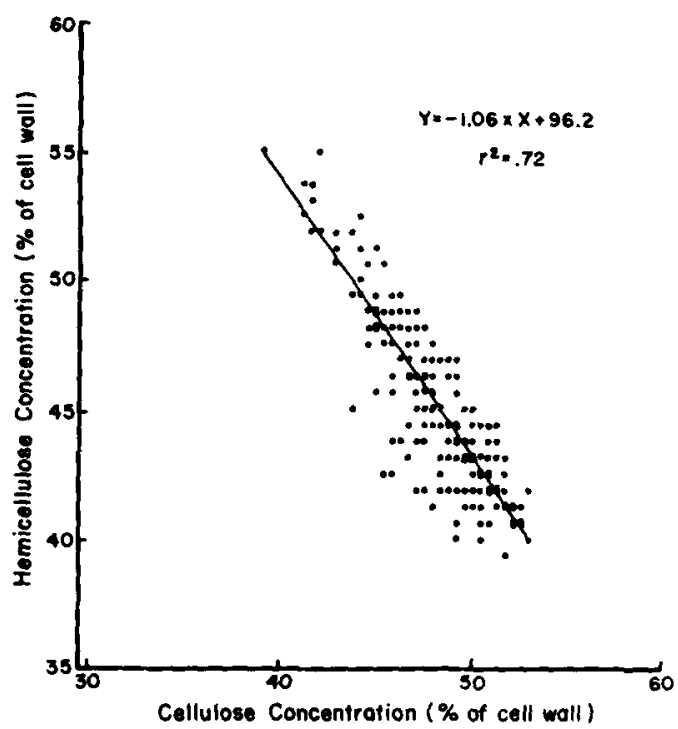

Figure 2. Change in hemicellulose concentration of grass cell walls in relationship to cellulose concentration.

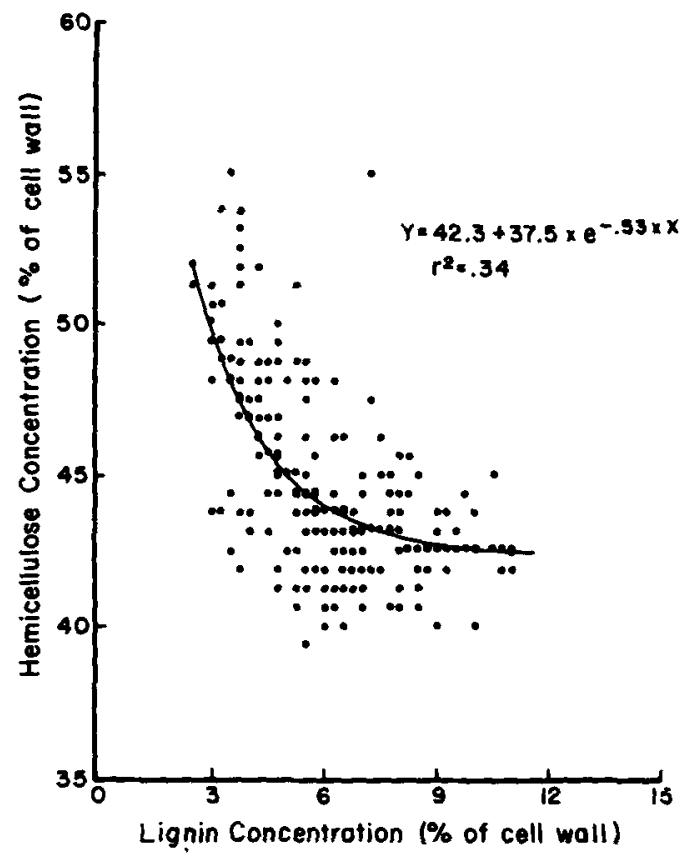

Figure 3. Relationship of cell wall hemicellulose concentration with lignin concentration. 


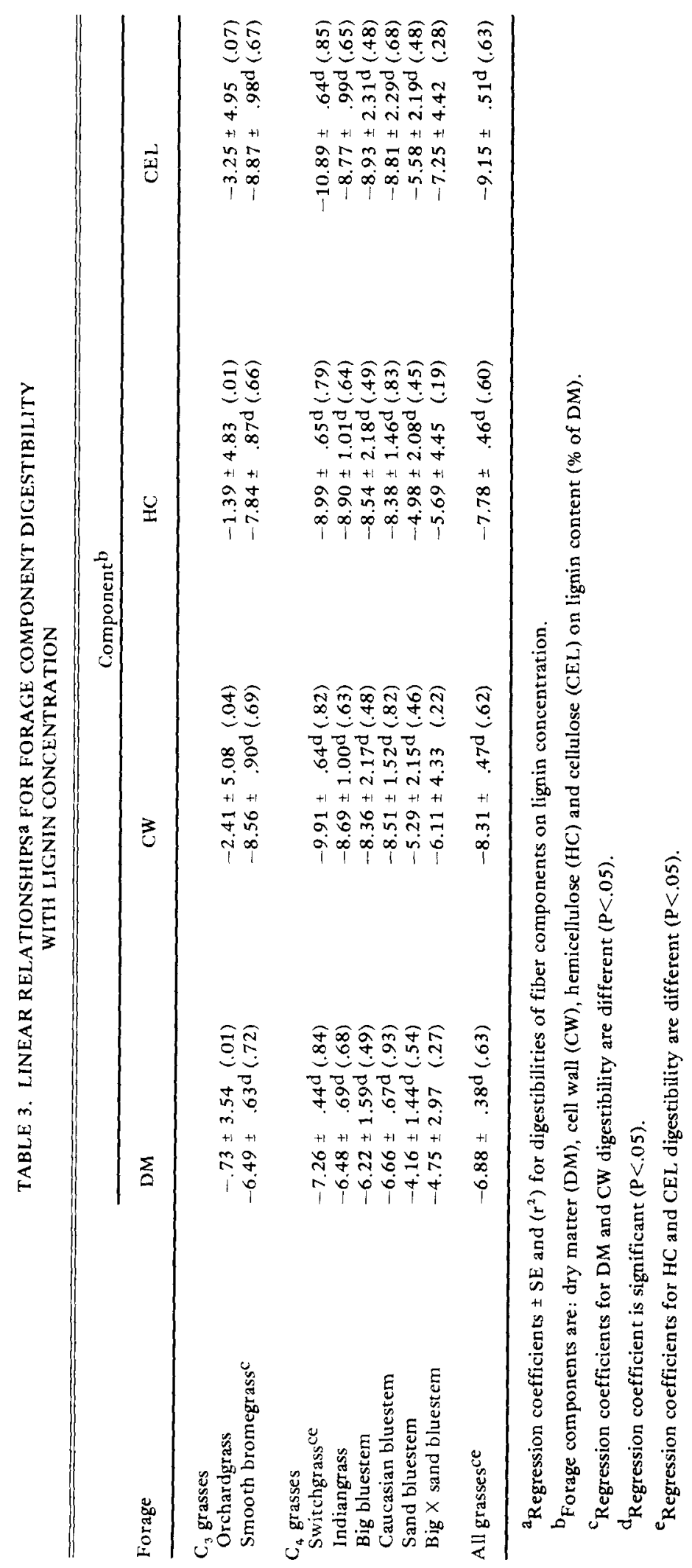


increased hemicellulose digestion to a greater extent than was the case for cellulose digestion. A similar effect was seen for delignification of pangola grass (Digitaria decumbens; Ford, 1978). The reason for this disparity between previous results and the data reported here may result from two potential technical causes. The other researchers used monosaccharide analysis of sulfuric acid hydrolyzed straw (Morrison, 1983) or trifluoroacetic acid hydrolysis of isolated hemicellulose (Ford, 1978) to calculate hemicellulose content and digestibility of their samples. Morrison (1980) recommends this procedure because of possible contamination of acid detergent fiber by hemicellulose sugar residues. In the experience of one of the authors (H. G. Jung, unpublished data), neither the sulfuric nor trifluoroacetic acid hydrolysis procedures results in complete hydrolysis of neutral detergent cell wall preparations, acid detergent fiber, isolated holocellulose or hemicellulose. If the sugar residues that are refractory to these procedures are also poorly digested, or not similar in composition to the hydrolyzed fraction, then the results may be biased. Another difficulty is the potential modification of the structural carbohydrates by the sodium chlorite:acetic acid solution used to delignify the forages. Any alteration of the inherent digestibility of cellulose or hemicellulose by the treatment would affect the results. The idea that the method of delignification could affect digestibility of structural carbohydrates is supported by the conflict between the results of Ford (1978) and Morrison (1983) compared with those of Bunting et al. (1984). Alternatively, if the acid detergent fiber samples in the current study were heavily contaminated wirh hemicellulosic sugars, as suggested by Morrison (1980), then the estimates of hemicellulose and cellulose could be biased. Use of the original detergent extraction procedure (Goering and Van Soest, 1970), or potassium permanganate rather than sulfuric acid (Muntifering, 1982), would probably also affect the results.

The site where the grass samples were collected affected the degree of inhibition in digestion attributable to lignin. The regression coefficients for forage component digestibility on lignin concentration were different $(\mathrm{P}<.05)$ for the two grass species collected at both sites (table 4). Samples from Clay Center showed greater inhibition of digestibility by lignin than did those collected at Mead. We assume that

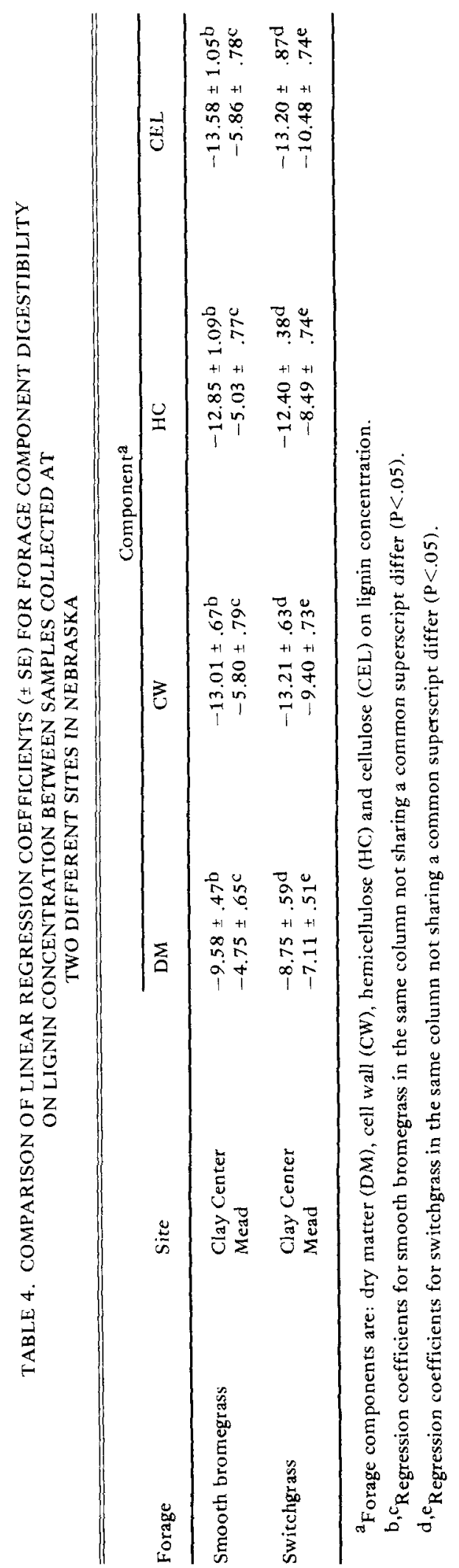


these differences are attributable to environmental effects on forage composition and digestibility as outlined by Van Soest et al. (1978) and Ford et al. (1979).

Although most studies of digestibility:lignin relationships have utilized a linear model, and found high degrees of correlation (Mowat et al., 1969; Minson, 1971; Ford, 1978; Ford et al., 1979), it has been suggested that the relationship may be curvilinear (Van Soest, 1967). A visual apprasial of the plotted data suggested that the digestibility:lignin relationships were curvilinear in nature rather than linear, even though the linear correlation coefficients were quite high. To test if a curvilinear model was more appropriate, the following equation was fit to the data:

$$
\text { Digestibility }=\mathrm{A}+\mathrm{Be}^{\mathrm{C} \cdot \mathrm{Lignin}}
$$

This equation was chosen because it describes an exponential relationship and gave relatively good fit to the data. The variable $C$ is an estimate of the relative degree of inhibition attributable to lignin. Biological or chemical significance was not assigned to the $A$ and $B$ variables. Linear and curvilinear models were compared by an F-test of the residual sums of squares.

Figures 4, 5, 6 and 7 illustrate the degree of fit for the curvilinear model. For all the measures of digestibility, the curvilinear model accounted for more $(\mathbf{P}<.05)$ of the variation in both the overall data set and for most of the individual species. This was true for lignin expressed as a percentage of dry matter or cell wall, and again, lignin on a dry matter basis gave the best fit. The data indicate that the inhibitory effects of lignin on digestibility are greatest at the low concentrations of lignin found in immature forages, but that as forages mature, lignin exerts an ever-decreasing influence on digestion, even though lignin concentration is rapidly increasing. The changing influence of lignin on digestibility because of maturation may result from the changes in lignin composition that are known to occur during maturation (Jung et al., 1983; Burritt et al., 1984). It has been demonstrated that the modified composition of brown-midrib corn lignin is correlated with improved digestibility (Cymbaluk et al., 1973).

The decreasing influence of lignin on digestion of forage at high lignin concentrations suggests an explanation of the observation that legumes, which contain more lignin than do grasses, exhibit less inhibition of digestibility by lignin than do grasses (Mowat et al., 1969). Data for bridsfoot trefoil (Lotus corniculatus) indicated that dry matter and cell wall digestion are related to lignin in a curvilinear man-

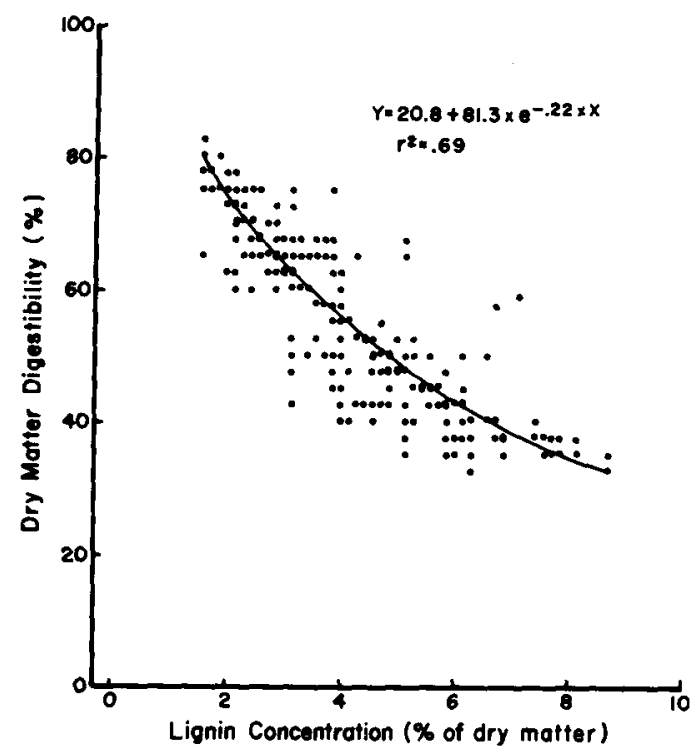

Figure 4. Effect of lignin concentration of grasses on dry matter digestibility.

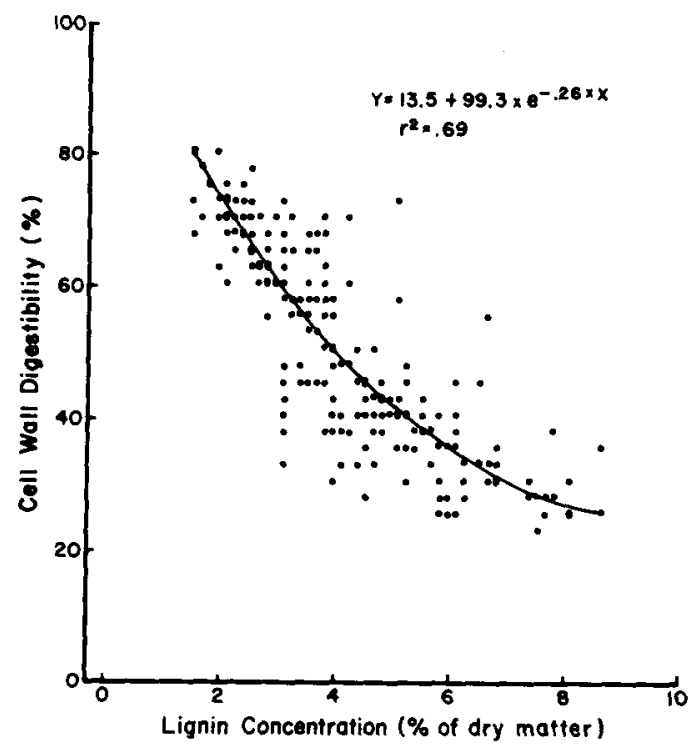

Figure 5. Effect of lignin concentration of grasses on cell wall digestibility. 
ner, but that the legume data describe a curve that is fundamentally different than that derived from grasses (H. G. Jung, unpublished data). It still appears that there is some basic difference in the structure of the cell wall matrices of grasses and legumes.

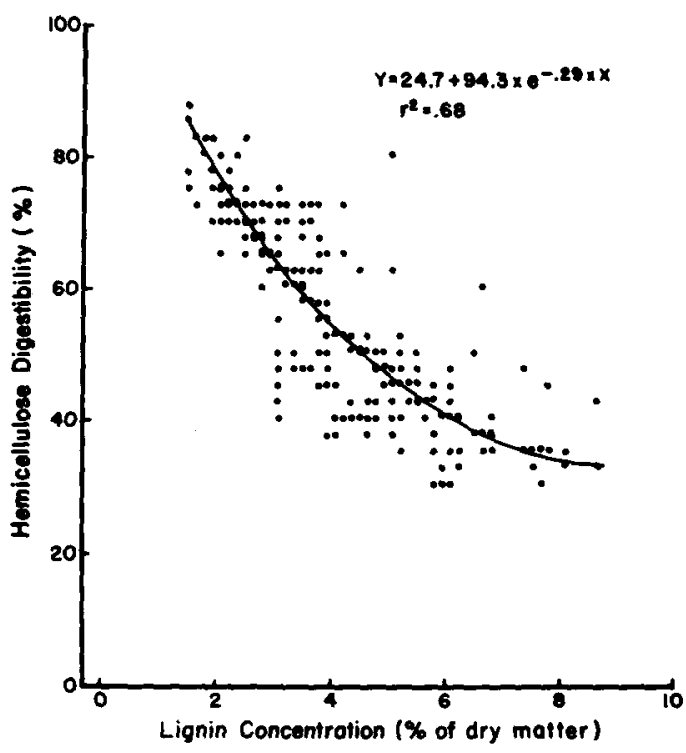

Figure 6. Effect of lignin concentration of grasses on hemicellulose digestibility.

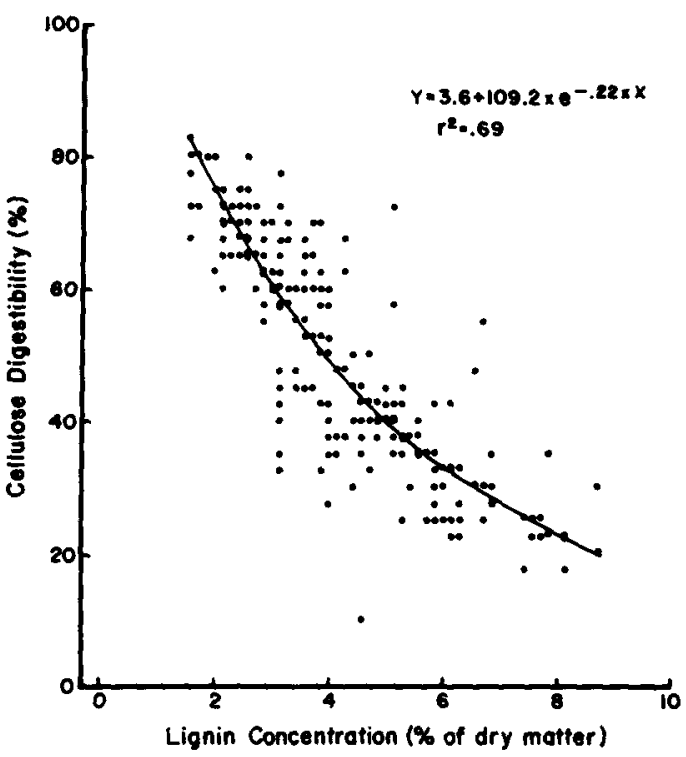

Figure 7. Effect of lignin concentration of grasses on cellulose digestibility.
A test of the original hypotheses using the $C$ variable in the curvilinear model showed no significant difference between dry matter $(-.219 \pm .068)$ and cell wall $(-.256 \pm .064)$ digestion, or hemicellulose $(-.291 \pm .068)$ and cellulose $(-.218 \pm .063)$ digestion as a function of lignin concentration.

The results of this study suggest that lignin inhibits cell wall digestion to a greater extent than that of total forage dry matter digestibility, as was predicted, if a linear model is assumed to be correct. The data do not support the hypothesis that hemicellulose digestibility, because of covalent linkage to lignin, is more strongly influenced by lignin than is cellulose digestion (Ford, 1978; Morrison, 1983). Resolution of this question will require more defined analytical procedures. The hypothesis that lignin influences extent, but not rate of forage digestion (Smith et al., 1971, 1972) should also be re-examined with improved analytical methodologies. The most significant result of this study may be the demonstration that the relationship of lignin with forage digestibility is curvilinear. Certainly this result suggests that the mechanism whereby lignin in hibits forage cell wall digestion is more complex than commonly believed.

\section{Literature Cited}

Akin, D. E. and D. Burdick. 1975. Percentage of tissue types in tropical and temperate grass leaf blades and degradation of tissues by rumen microorganisms. Crop Sci, 15:661.

Akin, D. E., J. R. Wilson and W. R. Windham. 1983. Site and rate of tissue digestion in leaves of $C_{3}$, $\mathrm{C}_{4}$, and $\mathrm{C}_{3} / \mathrm{C}_{4}$ intermediate Panicum species. Crop Sci. 23:147.

Allinson, D. W. and D. F. Osbourn. 1970. The cellulose-lignin complex in forages and its relationship to forage nutritive value. J. Agr. Sci. (Camb.) 74: 23.

AOAC. 1975. Official Methods of Analysis (12th Ed.). Association of Official Analytical Chemists, Washington, DC.

Bacon, J.S.D. 1979. Plant cell wall digestibility and chemical structure. Rep. Rowett Inst. 35:99.

Bunting, L. D., C. R. Richardson and R. W. Tock. 1984. Digestibility of ozone-treated sorghum stover by ruminants. J. Agr. Sci. (Camb.) 102: 747.

Burritt, E. A., A. S. Bittner, J. C. Street and M. J. Anderson. 1984. Correlations of phenolic acids and xylose content of cell wall with in vitro dry matter digestibility of three maturing grasses. J. Dairy Sci. 67:1209.

Cymbaluk, N. F., A. J. Gordon and T. S. Neudoerffer. 1973. The effect of the chemical composition of maize plant lignin on the digestibility of maize stalk in the rumen of cattle. Brit. J . Nutr. 29:1. 
Ford, C. W. 1978. Effect of partial delignification on the in vitro digestibility of cell wall polysaccharides in Digitaria decumbens (Pangola grass). Australian J. Agr. Res. 29:1157.

Ford, C. W., I. M. Morrison and J. R. Wilson. 1979. Temperature effects on lignin, hemicellulose and cellulose in tropical and temperature grasses. Australian J. Agr. Res. 30:621.

Goering, H. K. and P. J. Van Soest. 1970. Forage Fiber Analysis (apparatus, reagents, procedures and some applications). USDA Agr. Handbook 379, Washington, DC.

Griffin, J. L. and G. A. Jung. 1983. Leaf and stem forage quality of big bluestem and switchgrass. Agron. J. 75:723.

Jung, H. G., G. C. Fahey, Jr. and N. R. Merchen. 1983. Effects of ruminant digestion and'metabolism on phenolic monomers of forages. Brit. J. Nutr, 50:637.

McDougall, E. I. 1948. Studies on ruminant saliva: I. The composition and output of sheep's saliva. Biochem. J. 42:99.

Minson, D. J. 1971. Influence of lignin and silicon on a summative system for assessing the organic matter digestibility of Panicum. Australian J. Agr. Res. 22:589.

Morrison, I. M. 1979. Carbohydrate chemistry and rumen digestion. Proc. Nutr. Soc. 38:269.

Morrison, I. M. 1980. Hemicellulosic contamination of acid detergent residues and their replacement by cellulose residues in cell wall analysis. J. Sci. Food Agr. 31:639.

Morrison, I. M. 1983. The effect of physical and chemical treatments on the degradation of wheat and barley straws by rumen liquor-pepsin and pepsin-cellulose systems. J. Sci. Food Agr. 34: 1323

Mowat, D. N., M. L. Kwain and J. E. Winch. 1969. Lignification and in vitro cell wall digestibility of plant parts. Can. J. Plant Sci. 49:499.
Muntifering, R. B. 1982. Evaluation of various lignin assays for determining ruminal digestion of roughages by lambs. J. Anim. Sci. 55:432.

Smith, L. W., H. K. Goering and C. H. Gordon. 1972. Relationships of forage compositions with rates of cell wall digestion and indigestibility of cell walls. J. Dairy Sci, 55:1140.

Smith, L. W., H. K. Goering, D. R. Waldo and C. H. Gordon. 1971. In vitro digestion rate of forage cell wall components. J. Dairy Sci. 54:71.

SAS. 1982. SAS User's Guide: Statistics. Statistical Analysis System, Inc., Cary, NC.

Van Soest, P. J. 1967. Development of a comprehensive system of feed analyses and its application to forages. J. Anim. Sci. 26:119.

Van Soest, P. J., D. R. Mertens and B. Deinum. 1978 Preharvest factors influencing quality of conserved forage. J. Anim. Sci. 47:712.

Van Soest, P. J. and J. B. Robertson. 1980. Systems of analysis for evaluating fibrous feeds. In: W. J. Pigden, C. C. Balch and M. Graham (Ed.). Standardization of Analytical Methodology for Feeds. pp 49-60. Int. Dev. Res. Center, Ottawa, Canada. Pub. 1DRC-134e.

Waller, S. S. and J. K. Lewis. 1979. Occurrence of $\mathrm{C}_{3}$ and $C_{4}$ photosynthetic pathways in North American grasses. J. Range Manage. 32:12.

Wilkins, R. J. 1972. The potential digestibility of cellulose in grasses and its relationship with chemical and anatomical parameters. J. Agr. Sci. (Camb.) 78:457.

Wilman, D. and M.A.K. Altimimi. 1984. The in vitro digestibility and chemical composition of plant parts in white clover, red clover and lucerne during primary growth. J. Sci. Food Agr. 35:133.

Woodman, H. E. and J. Stewart. 1932. The mechanism of cellulose digestion in the ruminant organism. The action of cellulose-splitting bacteria on the fiber of certain typical feeding stuffs. J. Agr. Sci. (Camb.) 22:527. 